\title{
Crisis of conscience
}

The University of the South Pacific has become the centre of excellence in the region, as indeed any university of USP's nature should be. Apart from teaching and research, the university has in many ways become the critical conscience of the region.

\section{By BIMAN PRASAD}

THE UNIVERSITY of the South Pacific is a premier tertiary institution in the South Pacific and since its inception in 1968, it has served the university region well. It has been successful in developing appropriate human resources needed by the region for their economic and political development. It continues to serve the twelve countries which include, Cook Islands, Fiji, Kiribati, Marshall Islands, Nauru, Niue, Samoa, Tonga, Solomon Islands, Tokelau, Tuvalu, Niue, and Vanuatu. We have university centres in all these countries.

The USP has become the centre of excellence in the region, as indeed any university of USP's nature should be. Apart from teaching and research, the university has in many ways become the critical conscience of the region. As such it is expected to engage in debate and provide appropriate information, research and criticisms of government policies and indeed act as an institution which promotes good governance and human values in society.

The USP has done well so far and is likely to remain a premier institution in the region for some time. However, the pressures on it are many. These pressures are the result of increasing globalisation and a move towards managing the university based purely on market forces. The models of management being applied to universities in Australia and New Zealand are rapidly permeating into USP and it may not be sustainable in the long run, considering the needs of the region. The university is funded by the 12 member countries, but bulk of the funding comes from the Fiji government. Australia and New Zealand 


\section{BIMAN PRASAD}

are the major donors to USP.

USP salaries are also a cause for concern. At present our salaries are somewhere around 68 percent of the academic salaries in Australia and New Zealand. Unless there is an immediate increase in salaries of academic staff, it may become difficult to attract staff from overseas and retain qualified local staff at the university. The Association of USP staff is concerned about this and is currently working on this issue with the university management. Furthermore there are political pressures which affect the university's teaching, research and indeed academic freedom. Salman Rushdie, the controversial Indian novelist, once said

Writers and politician are natural rivals. Both groups try to make the world in their own images; they fight for the same territory. And the novel is one way of denying the official, politicians version of truth.

Once a country is going through a political crisis as Fiji is at the moment; the academics are like the novelists and natural rivals to the politicians. If the politicians carve the country in their own images, it becomes the duty of the academics to deny the politician's version of truth. This is where academic freedom becomes a crucial issue. Unrepresentative politicians are especially sensitive to criticisms. Academic freedom in fact is under attack from both official and unofficial quarters. Thugs can wear a variety of garbs-soldiers and police off or on duty; interim ministers, civil servants in positions of power and plain and simple thugs used by those who have hidden agendas. Just to give you a quick example, when some academics were protesting against the imposition racist 1990 Constitution, one particular academic, Dr Anirudh Singh was abducted tortured, and left for dead by thugs of one sort or another. Another case involves the army picking on two academics after they were involved in publishing a book condemning the Rabuka coups in 1987. One of these academics in particular was incarcerated and tortured in the military barracks. This open punishment was meant to frighten the rest of the academics from protesting against the illegal overthrow of the democratically elected government then. We are all very conscious this time around, that such treatments can be repeated now.

Because academics in some ways are the social conscience of a nation, they can be a threat to the politicians especially if they are un-elected. While local academics may fear retribution and incarceration, overseas academics often feel 


\section{Academics from} overseas often feel constrained by their speak up, even in their own subject areas, the threat of work permits being revoked is there. Academic freedom cannot be taken for granted in Fiji at the present moment. work permits. If they

constrained by the limitations of their work permits. If they speak up, even in their own subject areas, the threat of work permits being revoked is always there. In short, academic freedom cannot be taken for granted in Fiji at the present moment.

Since 19 May 2000 the staff at the university have worked under extreme anxiety and many have engaged in various forms of selfcensorship in terms of what they could have written and said about the illegal overthrow of the democratically elected government.

The Association of the University of South Pacific Staff (AUSPS) will continue to condemn and resist any political pressure to curb academic freedom at USP. In this respect AUSPS was very encouraged and delighted to receive the moral support from AUS and NTEU. It was most reassuring.

As a result of the 19 May 2000 coup, the University has been affected in a number ways. First, the effect on the students and staff has been very traumatic. There was constant disruption to the teaching on Laucala campus. Practical problems of timetabling, rescheduling of lectures and examinations, dismissing classes at the news of imminent trouble- in all this the technology was stretched to its limits. The first semester was rearranged with an early semester break. Some students did not return from other countries and were able to continue with their courses via our distance education programme.

About 40 staff have so far left the services of the university and it may become difficult to attract quality staff in certain disciplines in future, if the present crisis in Fiji continues. Of course, sometimes the exodus of certain staff is welcomed when they are known to be inefficient or simply bad. But often, the good ones are the first to leave, either by resigning or by not taking up further renewal of contract. Recruitment of replacement staff is not always positive under such de-stabilised condition. The best do not necessarily apply. In any case, the choice is limited. I must admit that the staff continued to discharge their

PACIFIC JOURNALISM REVIEW 7:1 200199 
teaching duties at the university despite the conditions of extreme anxiety and fear they were under. I am sure you can imagine the kind of academic environment we had when people carrying M16s and AK47s were roaming around the place and when the police and the military were unable to do much to restore peace and stability. In this kind of environment, you can't be expected to do serious academic work. However, despite all this, the university year has concluded fairly successfully.

Academic freedom is fundamental to the existence of any university but I must concede that we have not come out the best in this respect. The university management was very sensitive to the political crisis in Fiji and sometimes their actions and advice to staff bordered on curbing academic freedom.

The staff association was vigilant and took firm stand on issues that we felt were designed to promote self-censorship. For example, soon after the May 19 coup, the university administration in panic and unilaterally decided to close the journalism programme website. The journalism students were provided with a fabulous opportunity to practise skills in the real life situation what they were learning in theory. Their reporting on the crisis was appreciated around the world. The administration's drastic move to shut the website down was rather regrettable from the point of view of both staff and students of journalism. The Association of USP Staff protested vigorously against the closure and it was allowed to continue.

[Pacific Journalism Online in December won the Ossie Awards in Australia for the best student publication over its coverage of the Fiji coup.]

When one talks about USP, one has to consider that it serves 12 countries and that is why it is more important for the University to function properly and take a pro-active role in condemning all acts of violence and supporting the rule of law and good governance in its member countries. This is why it is critical that the USP continues to be supported by those who have provided help in the past. The support can be considered at two levels.

At the government level, both Australia and New Zealand have supported the university since its inception and continue to do so after the political crisis. They rightly recognise the regional nature of the university and have assured support for it. In fact, USP is the only institution which is well placed to provide the leadership in developing the human resource needs of the region. Furthermore, it is a lead institution in promoting the universal principles of human rights, democracy and good governance. For this specific role, USP needs continued support from governments like Australia and New Zealand. The 100 PACIFIC JOURNALISM REVIEW 7:1 2001 
tertiary education unions like yours can be in the forefront of promoting the role of the university in this regard. The potential of USP in the area of promoting human rights, democracy and good governance has perhaps not been realised fully. We hope that our co-operation with your association will provide us the will and drive to push for a proactive role of USP in these vital areas of basic human rights.

The AUSPS is an active participant in the affairs of the Fiji Trade Union Congress and indeed our members have provided moral and intellectual support to the Congress at all times including the critical period of the coup and its aftermath.

Let me now turn to the political situation in Fiji. I am sure that most of you are well informed through the media in New Zealand and therefore I am not going to bore you with the details of what has happened so far. However, I do want to reflect briefly on the impact of the political crisis and on the economy of Fiji. The impact on the economy is disastrous to say the least. The magnitude of the destruction is much worse than what was the case in 1987. It is likely to lake about $20-25$ years to make the economic recovery and get the country back on its feet. We are likely to face extreme economic hardship and poverty if we do not get back to constitutional rule and democracy as soon as possible.

First investment levels have declined significantly since the coup and this trend is likely to continue for a long time. The interim regime has just brought out a budget, which it says is designed to build the foundation for economic recovery. The net budget deficit forecast is about four percent of the total GDP and but most of the expenditure is for operational purposes. Capital expenditure just represents about 18.5 percent of the total expenditure and this is not likely to create much economic activity and employment.

The interim regime has put forward an investment package designed to attract both domestic and foreign investment. For example duty on construction materials and capital goods has been reduced from 10 to 3 percent and no duty on inputs for companies who produce goods for export. Furthermore investment allowances and accelerated depreciation is now available for companies who are involved in value adding and knowledge based industries.

Corporate taxes have been reduced from 45 percent to 34 percent for foreign companies and exemption of taxes on dividends. All these are desperate measures to attract investment, which is badly needed for some economic rejuvenation. One thing, however, is very clear: investment is not only responsive to economic incentives but is very sensitive to external factors such as 
With the economy affected badly, the political crisis has had a major impact on employment and poverty. While official estimates show that about 7000 workers have lost their jobs, the real figure is much higher. Official figures don't include reduced hours. political stability, certainty of property rights and the rule of law. All these are going to be the real deciding factors for investor choosing to invest in Fiji.

With the economy affected badly, the political crisis has had a major impact on employment and poverty. While official estimates show that about 7000 workers have lost jobs, the real figure, in my view, is much higher. The official figures do not include the reduced working hours forced on the employees and those in the lower income brackets affected by the pay cuts.

Civil service pay-cuts of 12.5 percent have been restored from the December. However, the public sector unions filed a trade dispute and the tribunal ruled last week that it should be restored from August. The interim administration is looking at the option of further borrowing to pay the civil servants salary backdated to August 2000.

Unemployment and low wages are the major causes of poverty in Fiji. Before the crisis we had about 25 percent of the population living below the poverty line. The reintroduction of 10 percent VAT tax on basic food items such as rice, flour, tea, edible oils, tinned fish and powered milk is going to affect the poor and low wage eurners the most. We are likely to see more people moving below the poverty line. As a result of this, more social problems such as crime and suicide are likely to increase in Fiji. The other major problem is the expiry of land leases and the eviction of largely Indo-Fijian tenants from the land. 83 percent of the land in Fiji is communally owned by the indigenous Fijians and the majority of the tenants are Indo-Fijians. The Interim Administration's budget for 2001 has an allocation of $\$ 2.5$ million for resettlement of evicted tenants which at the rate of $\$ 10,000$ compensation per tenant will only cater for 250 farmers for their resettlement. In 2001 alone 1494 leases will expire and these Indo-Fijians tenants will have no where to go. Refugee camps will be the most reluctant choice for many of these families.

102 PACIFIC JOURNALISM REVIEW 7:1 2001 
The large-scale non-renewal of leases is going to create a major humanitarian disaster if the Interim Administration continues to take a totally racial approach to solving the land problem. What we are likely to see is the total destruction of the sugar industry and declining agricultural productivity. About 60-65 percent of the people in Fiji still live in rural areas and the land lease problems are likely to create a lot of uncertainty and instability in the agricultural sector. This will force mass exodus of people into the urban areas. The urban sector is unlikely to absorb the people and we are sure to experience increased level of urban poverty in Fiji and not to mention associated social evils.

The impact on education has been enormous. The disruption of classes since May 19 has together with the economic downturn affected most of the schools in Fiji. In Vanua Levu, the second largest island in Fiji each school has lost an average of 33 students. This is where the terrorists had taken over the military barracks and all the police stations.

The political scene in Fiji is still very uncertain and there is total confusion as to what is likely to happen in future. The ruling by the High Court that the 1997 Constitution was still intact and its abrogation by the military was illegal has created another dimension to the problem. The Interim Administration has of course challenged the decision and appeal on the matter is still pending. It is a case of an illegal regime talking about legality.

The thoroughly discredited Constitutional Review Commission to formulate a new constitution for Fiji continues to hear submissions from the public. The Indo-Fijian community, however, has virtually boycotted the review and not many indigenous Fijians are giving submission to the committee.

Unfortunately, a USP professor of Pacific Studies, Professor Asesela Ravuvu, who has been known for his anti-democratic stand since 1997, chairs the committee. While this particular professor has his academic freedom to express his views, however biased or racist they might be (for example, he has gone on record saying that politics takes precedence over the rule of law and openly advocates supremacy of one race over another), while this is going on, criticism of members of this hand-picked review commission is officially not tolerated.

The commission is seen by most as biased and has people in it who were directly supporting George Speight and his group. The Interim Administration has continued with the review despite the resounding opposition to it by the political parties, the trade union movement and other key civil society organisations and the NGO coalition for democracy. The review commission's terms 


\section{BIMAN PRASAD}

of reference make it abundantly clear that the interim regime is determined to impose an ethnically supremacist and discriminatory constitution on the people of Fiji. It is very clear that the interim regime, which includes terrorists supporters, is hell bent on continuing to illegally govern Fiji and to impose a racist constitution, thereby making one half of the population second class citizens. The AUSPS supports the trade union position through the Fiji Trade Union Congress that the 1997 constitution is still the best option for Fiji and if changes are made they should be done within the provisions of that Constitution.

Meanwhile, the interim regime continues to change policies and further the agenda and demands of the terrorists. For example, it has unilaterally decided to transfer state land to native land and it is planning to change other laws relating to land, labour, taxation, the judiciary and public services.

The trade union movement in Fiji is concerned with the intention of the interim administration to promulgate an Internal Security Decree. The decree is intended to seriously curb human and trade union rights. It is likely to implement wide-ranging restrictions on freedom of speech and movement. This decree is intended for those who may resist the interim government's racist agenda. The AUSPS will support the Fiji Trade Union Congress in its efforts to resist any such draconian laws which may be imposed by the interim regime.

The role of university academics at the University of the South Pacific, and by our friends in Australia and New Zealand, will be critical in upholding the rule of law and promoting universal principles of democracy and human rights in the South Pacific region.

The most serious threats to security and progress are the internal conflicts in many of the South Pacific Island countries. These contlicts arise largely out of the false belief in some quarters in the South Pacific, including Fiji, that democracy is a foreign concept or foreign flower. The guarantee of democratic principles based on respect for the rule of law and human rights is a fundamental requirement for progress and development not only in Fiji but in all other countries in the South Pacific Region. Universities and their staff will play a. critical role in this area.

Dr Biman Prasad is a senior economics lecturer and president of the Association of USP Staff. He gave this keynote address to the annual conference of the New Zealand Association of University Staff at Wellington, 4-5 December 2000. It was also published in NZ Educational Review under the title of "Crisis of conscience" on December 8. chand_b@usp.ac.fj

104 PACIFIC JOURNALISM REVIEW 7:1 2001 